\title{
WACANA APEC: LEGITIMASI DAN SIGNIFIKASI PEREKONOMIAN BALI (KAJIAN WACANA KRITIS PARAWISATA)
}

\author{
Hugo Warami \\ Universitas Papua \\ warami_hg@yahoo.com \\ Putu Chrisma Dewi \\ Universitas Dhyana Pura \\ chrismadewi@yahoo.co.id
}

\begin{abstract}
ABSTRAK
Makalah ini membahas tentang diplomasi bahasa yang dalam tulisan ini, istilah tersebut merujuk pada suatu cara, suatu strategi, suatu kiat, atau suatu taktik atau suatu kebijkan yang dirancang secara sitematis dan terstruktur untuk mengembangkan dan membina bahasa (Indonesia) baik secara internal maupun eksternal. Hasil analisis menunjukkan bahwa diplomasi bahasa mampu dijabarkan dalam tiga poin berikut yang terbukti sangat efektif untuk mempertahankan dan melestarikan bahasa daerah dalam rangka memperkaya keragaman bahasa nasional. Ketiga hal dimaksud adalah (1) pemodelan solusi konflik komunitas atau multibahasa, (2) penyebaran bahasa negara dan peningkatan fungsi bahasa Indonesia menjadi bahasa internasional, khususnya pada forum Perserikatan Bangsa-Bangsa (PBB), menguatkan identitas ke-Indonesia-an melalui penyebaran bahasa Indonesia dan (3) peningkatan kompetensi berbahasa asing strategis dan penerjemah.
\end{abstract}

Kata kunci: $A P E C$, Legitimasi, dan Signifikasi

\begin{abstract}
APEC discourse in this study shall be explored through critical paradigm to conduct reflexive construction on the experience of tourism discourses that grow and develop in the society of tourism in Bali. The focus of this study on the APEC discourse includes (1) legitimate and (2) signification of discourse construction which directliy impact on economy of Bali through critical discourse analysis (CDA). This perspective provides the emphasis on tourism determination and creative aconomy, that is everything that in progress, will and later happens through APEC discourse, and directly impact on the economic power. Legitimate will assist to make objectivation which is formed to be availabled objectively and make sense subjectively. While, signification is one of discourse structure which refer to a system obliged to the available of relation which can not be separated between a sign and reality which becomes its reference and also has the iconic characteristic. APEC 2013 which is said to be conducted in Bali, will has a big impact on the development of tourism sector. At least, signification of change and the dynamics which occur in national, regional, and international level will be constructed and utilized collectively in solving the same problems among APEC countires. For CDA analysis, the language fact is obtained from the mass media (Bali local newspaper), those are (1) Bali Post and (2) Media Bali Promosi.
\end{abstract}

Keywords: APEC, Legitimate, and signification

\section{PENDAHULUAN}

Asia Pasifik Economics Coorporation
(APEC) merupakan salah satu wacana konstruksi bahasa yang sedang dilegitimasi 
melalui media-media massa dan elektronik di Bali pada sektor jasa pariwisata. Bagi media, APEC menjadi sebuah realitas yang dikonstruksikan menjadi sebuah wacana. APEC dalam konstruksi wacana pariwisata, kehadirannya dijadikan sebagai media dalam mendominasi, menguasai, mengarahkan pikiran publik, merekonnstruksi realitas masyarakat Bali dan menanamkan ideologi-ideologi baru. Realita menunjukkan bahwa saat ini media merupakan saluran pemerintah dalam rangka melegitimasi dan mensignifikasikan kepentingan kekuasaan yang bermuara pada kekuasaan politik dan ekonomi.

Dalam konteks media massa, konstruksi leksikon APEC dapat dijadikan barang dagangan dan objek dalam menyalurkan informasi massa. Proses penyebaran informasi APEC dapat menjadi alat legitimasi dan signifikasi dalam upaya menumbuhkembangkan prekonomian Bali sekaligus mendorong terciptanya prospek pariwisata yang menjanjikan. Selain itu, dalam konteks wacana pariwisata, media promosi APEC diharapkan menjembatani dunia kapitalis dan keberpihakan pada masyarakat serta keberpihakan pada sektor jasa pariwisata pada umumnya. Konstuksi informasi APEC harus sampai pada khalayak secara tepat berdasarkan tujuan dan kepentingan agen atau aktor serta menempatkan diri bagi masyarakat Bali sebagai pemirsa atau pembaca yang ikut merasakan, melihat, dan menikmati signifikasi wacana APEC 2013 tersebut.

APEC sebagai wacana pariwisata dalam kajian ini akan dieskplorasi melalui paradigma kritis. Paradigma kritis akan digunakan untuk melakukan konstruksi refleksif terhadap pengalaman wacanawacana pariwisata yang tumbuh dan berkembang pada masyarakat pelaku pariwisata di Bali. Wacana APEC dalam paradigma kritis dalam memahami teks-teks yang mengendap makna alamiah maupun makna non alamiah dalam bidang pariwisata. Kajian legitimasi dan signifikasi konstruksi wacana APEC yang berdampak langsung pada perekonomian Bali khususnya bidang pariwisata termasuk dalam kerangka perspektif critical discourse analysis (CDA). Perspektif ini memberikan penekanan pada determinasi pariwisata dan ekonomi kreatif, yakni segala sesuatu yang sedang, akan, dan nanti terjadi melalui wacana APEC, dan berdampak langsung pada kekuatan-kekuatan ekonomi.

Selain itu, keterlibatan Indonesia pada forum-forum multilateral menurut Petranto (2012:17-18), biasanya memiliki sesi khusus yang berisi penyampaian pandangan negara-negara dalam sesi perdebatan umum, atau lebih dikenal dengan istilah General Debate. Dalam ruang tersebut, Indonesia menyampaikan statement 
yang pada intinya menekankan tentang tantangan global, seperti perubahan iklim, ketahanan pangan dan energi, serta fluktuasi harga komoditas. Persoalan tersebut saling terkait satu sama lain dan harus diselesaikan melalui kemitraan global yang koheren dan solid. Dewasa ini, di mana perkembangan global dihadapkan pada berbagai tantangan krusial di bidang keuangan, makro-ekonomi dan perdagangan, peran forum multilateral menjadi semakin penting, guna menjalankan program research, inter-governmental discussion, dan technical assistance, yang perlu terus dikembangkan dengan dukungan dari berbagai pihak yang berkepentingan.

Mengacu pada pandangan Pilliang (2004:69), bahwa dengan kuatnya kepentingan ekonomi dan kekuatan politik, sesungguhnya media tidak netral, jujur, adil, dan terbuka. Akibatnya, informasi yang disungguhkan oleh media akan menimbulkan persoalan objektivitas pengetahuan yang serius pada media itu sendiri. Kepentingan-kepentingan ekonomi dan kekuasaan politik akan menentukan apakah informasi yang disampaikan oleh sebuah media mengandung kebenaran (truth) atau kebenaran palsu (pseudo-truth); menyampaikan objektivitas atau subjektivitas; bersifat netral atau berpihak; merepresen- tasikan fakta atau memelintir fakta; menggambarkan realitias (reality) atau menyimulasi realitas (simulacrum). Berangkat dari uraianuraian di atas, maka kajian ini akan memfokuskan pada upaya pengungkapan "Wacana APEC: Legitimasi dan Signifikasi Perekonomian Bali" melalui bedahan Critical Discours Analysis pada wacana pariwisata. Kajian ini akan memproyeksikan masalah yang mencakup: (i) legitimasi media pada jasa pariwisata Bali, dan (ii) signifikasi wacana APEC yang berdampak pada perekonomian Bali.

\section{KONSEP DAN KERANGKA TEORI KONSEP}

\section{KONSEP LEGITIMASI}

Legitimasi menghasilkan maknamakna baru yang berfungsi untuk mengintegrasikan makna-makna yang sudah diberikan kepada proses-proses kelembagaan yang berlainan. Fungsi legitimasi adalah untuk membuat obyektivasi yang sudah dilembagakan menjadi tersedia secara obyektif dan masuk akal secara subyektif. Hal ini mengacu kepada dua tingkat, pertama keseluruhan tatanan kelembagaan harus dapat dimengerti secara bersamaan oleh para pesertanya dalam proses-proses 
kelembagaan yang berbeda. Kedua keseluruhan individu (termasuk di dalam media ), yang secara berturut-turut melalui berbagai tatanan dalam tatanan kelembagaan harus diberi makna subyektif. Masalah legitimasi tidak perlu dalam tahap pelembagaan yang pertama, dimana lembaga itu sekedar fakta yang tidak memerlukan dukungan lebih lanjut . Tapi menjadi tak terelakan apabila berbagai obyektivasi tatanan kelembagaan akan dialihkan kepada generasi baru (bd.van Leeuwen, \& Wodak, 1999). Di sini legitimasi tidak hanya sekedar soal "nilainilai" ia juga selalu mengimplikasikan "pengetahuan". Sedangkan signifikasi menurut Giddens (2010:49) merupakan salah satu struktur wacana yang mengacu pada sistem, mengharuskan adanya relasi yang tidak dapat dipisahkan antara sebuah tanda dan realitas yang menjadi rujukannya serta bersifat ikonis.

\section{KONSEP ANALISIS WACANA KRITIS}

Analisis wacana kritis (AWK) yang diindonesiakan dari konsep Critical Discourse Analysis (CDA) memiliki beberapa konstruksi konsep, menurut Fairclough dan Wodak (1997: 271); Jorgensen dan Phillips (2007: 115168) yang mencakup: (1) bentuk praktik sosial yang menyusun dunia sosial dan disusun oleh praktikpraktik sosial dan wacana berada dalam hubungan dialektik dengan dimensi-dimensi sosial yang lain, (2) bentuk analisis tekstual linguistik yang konkret atas penggunaan bahasa dalam interaksi sosial, dan (3) bentuk praktik kewacanaan memberikan kontribusi bagi penciptaan dan pereproduksian hubungan kekuasaan yang tak setara antara kelompok-kelompok sosial. Selain itu, analisis wacana kritis menekankan perlu adanya kerja sama interdisipliner dalam rangka untuk mendapatkan pemahaman yang tepat tentang bagaimana bahasa menjalankan fungsinya sebagai transmisi pengetahuan dalam mengorganisasi lembaga sosial atau dalam menjalankan kekuasaan. Konsep analisis wacana kritis yang dikemukakan oleh Fairclough dan Wodak (1997: 271); dan Jorgensen dan Phillips (2007: 115-168) sejalan dan saling mengisi sehingga dapat dipakai sebagai pijakan dasar dalam penelitian ini. Berdasarkan pendapat-pendapat di atas, maka konsep analisis wacana kritis dalam

\section{KERANGKA TEORI}

Van Leeuwen

(2008:105-119)

mengungkapkan bahwa konstruksi 
legitimasi dapat dipergunakan untuk memahami aktor atau agen di balik wacana-wacana yang memarjinalkan kelompok tertentu. Konstruksi teori dalam kajian ini mengadopsi model cara kerja van Leeuwen yang terdiri atas empat bagian, yakni

authorization: tipe legitimasi yang mengacu kepada otoritas tradisi (kebiasaan), hukum, dan orang dalam institusi yang menegakkan otoritas tersebut, (2) moral evaluation: tipe legitimasi yang mengacu kepada sistem nilai-nilai sosial,

rationalization: tipe legitimasi yang mengacu kepada tujuan aksi-aksi terinstitusi, dan (4) mythopoesis: tipe legitimasi yang disampaikan melalui naratif.

\section{MODEL ANALISIS VAN LEEUWEN}

\section{DALAM MEMBEDAH KAJIAN}

\section{WACANA KRITIS}

CDA dapat digolongkan ke dalam praktik-praktik kewacanaan seperti yang dikemukakan oleh Fairclough dan Wodak (1997: 271); Jorgensen dan Phillips (2007: 115-168) sebagai berikut: (1) sifat struktur, proses kultural dan sosial sebagai linguistik -kewacanaan, yakni memiliki bentuk praktik sosial yang memberikan kontribusi bagi penyusunan dunia sosial yang mencakup hubungan hubungan dan identitas-identitas sosial dan terbentuk melalui praktik-praktik kewacanaan dalam kehidupan sehari-hari serta terjadi perubahan dan reproduksi kultural dan sosial. Ciri ini menjelaskan dimensi linguistik-kewacanaan fenomena sosial, kultural, dan proses perubahan dalam modernitas terkini, (2) sifat konstitutif dan tersusun (teratur). Ciri ini tidak hanya memberikan kontribusi pada pembentukan dan pembentukan kembali struktur sosial, namun merefleksikan pembentukan dan pembentukan kembali struktur sosial tersebut, (3) sifat empiris dalam konteks sosial. Ciri ini berpandangan jauh berbeda dengan teori wacana yang tidak melaksanakan kajian empiris dan sistematis penggunaan bahasa dan 64 berbeda dengan psikologi kewacanaan dalam melakukan kajian retoris yang bukan kajian linguistik penggunaan bahasa, (4) sifat ideologis dalam fungsi wacana. Ciri ini mengungkapkan wacana antara kelas-kelas sosial, perempuan dan laki-laki, kelompok minoritas dan mayoritas etnis. Efek-efek tersebut dipahami sebagai efek ideologis, dan (5) sifat kritis, yakni CDA atas nama emansipasi, pendekatan analisis wacana kritis memihak pada kelompok-kelompok yang tertindas. Hal inilah yang menjadi konsen Fairclough, yakni "kritik eksplanatoris" dan "kesadaran bahasa kritis". Konstruksi kerangka yang dikemukakan oleh Fairclough merupakan salah salah bentuk untuk 
menganalisis wacana sebagai praktik sosial karena berisi sederet konsep yang berbeda, saling berkaitan satu sama lain sebagai dimensi yang kompleks.

Prinsip dasar CDA telah dikemukakan oleh beberapa ahli menurut cara pandangnya sendiri-sendiri (Fairclough dan Wodak, 1997: 258-284, van Dijk, 1997: 1-37, Wodak dan Meyer, 2001). Beberapa pandangan tentang prinsip dasar itu memiliki kesamaan dalam pendekatan CDA, namun ada juga yang berpandangan kontroversial. Pandangan tentang prinsip dasar CDA yang banyak dirujuk ialah yang dikemukakan oleh Fairclough dan Wodak (1997), yakni dengan mengemukakan delapan prinsip dasar CDA, yakni (1) berorientasi pada masalahmasalah sosial dan tidak hanya memfokuskan diri pada penggunaan bahasa, tetapi juga pada karakteristik linguistik dalam proses sosial budaya (CDA berupaya mengungkap hubungan kekuasaan eksplisit yang sering tersembunyi), (2) 65 berhubungan dengan wacana kekuasaan (hubungan sosial dan kekuasaan itu dilakukan dan dinegosiasikan melalui wacana), (3) dapat mengungkap hubungan masyarakat dan budaya (penggunaan bahasa dapat mampu berkontribusi dalam memproduksi dan mengubah pola pikir dalam hubungan masyarakat, budaya, dan kekuasaannya), (4) melakukan kerja ideologi (ideologi diproduksi melalui Dimensi teks, praksis wacana, dan efek sosial yang dimiliki), (5) berhubungan dengan wacana sejarah (faktor ekstralinguistik: budaya, masyarakat, dan ideologi dalam hal sejarah), (6) dapat memediasi hubungan antara teks dan masyarakat (koneksi antara proses sosial budaya masyarakat dan sifat dengan struktur teks untuk melihat “perintah wacana"), (7) menjalankan prinsip interpretatif (penjelasan yang dinamis dan terbuka akan informasi yang kontekstual), dan (8) merupakan bentuk aksi sosial (model paradigma ilmiah sosial yang berkomitmen membawa perubahan dalam praktik komunikasi dan sosial politik).

\section{MEKANISME KERJA MODEL FAIR- CLOUGH}

Model tiga dimensi Fairclough diharapkan dapat memberikan kerangka analitis bagi analisis wacana. Model ini didasarkan pada prinsip yang berbunyi bahwa teks hanya dapat dipahami atau dianalisis secara terpisah, hanya dapat dipahami dalam kaitannya dengan jaring-jaring teks lain dan hubungannya dengan konteks sosial 
(Fairclough, 1992: 71,73: 136; 1995:

$60)$.

Tabel 1. Hubungan Jaring-jaring teks dengan Konteks Sosial

\begin{tabular}{|c|c|c|c|c|}
\hline \multirow{2}{*}{ Teori/Model } & \multirow{2}{*}{ Parameter } & \multicolumn{3}{|c|}{ Tahapan Analisis } \\
\hline & & Ontologis & Epistimologis & Aksiologis \\
\hline CDA-LF & $\begin{array}{l}\text { Otorisasi } \\
\text { Wacana }\end{array}$ & $\begin{array}{l}\text { Bahasa sebagai } \\
\text { praksis sosial } \\
\text { (hukum dan politik); } \\
\text { bahasa } \\
\text { kons-truksi sosial; } \\
\text { konst-itutif; } \\
\text { struktur bahasa; efek } \\
\text { wacana }\end{array}$ & $\begin{array}{c}\text { Pendekatan } \\
\text { Otoritas } \\
\text { Pendekatan } \\
\text { Normatif } \\
\text { Abstraksi Bentuk }\end{array}$ & $\begin{array}{l}\text { Sistem } \\
\text { Langue }\end{array}$ \\
\hline CDA-LF & $\begin{array}{c}\text { Satuan } \\
\text { Teks } \\
\text { Naratif }\end{array}$ & $\begin{array}{l}\text { Bahasa alat produksi } \\
\text { wacana; } \\
\text { media legiti-masi; } \\
\text { politik } \\
\text { simbol; alat kohesi } \\
\text { tekstual; } \\
\text { relasi makna }\end{array}$ & $\begin{array}{l}\text { Pendekatan Kritis } \\
\text { Pendekatan } \\
\text { Normatif } \\
\text { Abstraksi Makna }\end{array}$ & $\begin{array}{l}\text { Sistem Pa- } \\
\text { role }\end{array}$ \\
\hline CDA-LF & $\begin{array}{l}\text { Geneologi } \\
\text { Sosial }\end{array}$ & $\begin{array}{l}\text { Bahasa praktik keku } \\
\text {-asaan; } \\
\text { identitas sosial; pe- } \\
\text { nata } \\
\text { hubungan so-sial; } \\
\text { ruang } \\
\text { pengala-man; peru- } \\
\text { bahan } \\
\text { sosial; produksi } \\
\text { kekuasaan; } \\
\text { subjek sosial; prak- } \\
\text { tik } \\
\text { kewacanaan; }\end{array}$ & $\begin{array}{c}\text { Pendekatan } \\
\text { Otoritas } \\
\text { Pendekatan Kritis } \\
\text { Abstraksi Fungsi }\end{array}$ & $\begin{array}{c}\text { Sistem } \\
\text { Representasi }\end{array}$ \\
\hline CDA & Ideologi & $\begin{array}{l}\text { Bahasa permainan } \\
\text { simbol; } \\
\text { distorsi hubungan } \\
\text { sosial; } \\
\text { usaha mempertahan- } \\
\text { kan } \\
\text { kekuasaan; }\end{array}$ & $\begin{array}{l}\text { Pendekatan Kritis } \\
\text { Abstraksi Nilai }\end{array}$ & $\begin{array}{l}\text { Sistem } \\
\text { Semiologi }\end{array}$ \\
\hline
\end{tabular}

\section{CORPUS DATA}

Dalam analisis CDA tentang wacana APEC 2013 yang akan mengeksplorasi legitimasi dan signifikasi perekonomian Bali, fakta bahasanya diperoleh dari media massa (surat kabar lokal Bali), yakni (1) Bali Post, 14 Desember 2012 dan (2) Media Bali Promosi, Edisi Mei 24 Mei - 30 Mei 2013. Eksplorasi media sebagai corpus data dapat disajikan sebagai berikut.

Teks 1: APEC 2013

\section{APEC 2013}


Denpasar (Bali Post)

Bali sebagai tuan rumah Asia Pasific Economic Coorporation (APEC) 2013 diharapkan berdampak signifkan dan luas terhadap pertumbuhan ekonomi Bali. Setidaknya, APEC 2013 akan mendorong pertambahan jumlah kunjungan wisatawan hingga 5 juta orang.

Ketua umum Kamar Dagang dan Industri (Kadin) Badung, A.A.Ngurah Alit Wiraputra, SH., MH., memprediksi dampak dari APEC 2013 akan mendorong jumlah kunjungan wisatawan hingga 4,5-5 juta orang. Hal ini akan memberikan peluang bagi usaha seperti sewa kendaraan, guide, travel, dan jasa penunjang wisata lainnya.

"Semua sektor akan bergerak. Apalagi, Badung sebagai tuan rumah akan menikmati sekali, bahkan bisa mendorong pertumbuhan ekonomi hingga dua digit," ujar Alit Wiraputra, Kamis (13/12) kemarin.

Selain itu, investasi di sektor perhotelan yang digarap tahun ini akan dioperasikan pula pada 2013 mendatang. Jika tahun 2010 lalu jumlah hotel berbintang lima di Badung sebesar 41 unit, namun kini sudah mencapai 68 unit.

Menurutnya, produk makanan dan minuman yang dimanfaatkan kalangan hotel selama ini 80 persen dipasok dari luar akibat tidak ada regulasi yang jelas mengatur porsi penyerapan produk lokal ke hotel. "Ini harus kita rebut. Bali mesti mampu meningkatkan pasokan ke hotel maupun restoran yang ada di daerah ini," serunya.

Selama ini penggunaan produk lokal baru sebatas himbauan saja. Mestinya hal itu sudah ada regulasi untuk pembelaan atau penggunaan produk lokal. Regulasi ini harus datang dari pemerintah tingkat I. "Kami dari Kadin Badung juga ikut mendorong untuk segera dikeluarkan regulasi dalam melindungi produk lokal. Di samping adanya keberpihakan terhadap produk kita," jelasnya.

Di samping itu peluang yang sudah tampak di tahun 2013 mendatang, Badung juga diharapkan pada berbagai persoalan. Salah satunya dengan meningkatnya jumlah wisatawan dan faktor penunjangnya yang terkonsentrasi di Badung Selatan, otomatis membuat akses ke kawasan tersebut makin macet. Persoalan lainnya juga muncul pada volume sampah di Badung Selatan yang makin meningkat.

"Jumlah pencari kerja juga kian bertambah dan tingkat polusi udara yang makin memprihatinkan. Faktor lain yang tidak kalah pentingnya adalah energi seperti listrik dan pasokan air bersih. Ini menjadi PR bagi pemerintah Badung," tandasnya.(kmb27).

Sumber: Surat Kabar Harian Nasional Bali Post, Edisi Jumat, 14 Desember 2012

Teks 2: APEC Berpotensi Dongkrak MICE di Bali

\section{APEC Berpotensi Dongkrak MICE di Bali}

Bali Promosi 
Praktisi pariwisata memastikan Konferensi Tingkat Tinggi APEC 2013 di Bali mendongkrak kinerja Meeting, Incentive, Converence, Exhibition (MICE) di tahun mendatang.

Tjokorda Oka Artha Ardana Sukawati, Ketua Badan Promosi Daerah (BPPD) Bali, mengatakan KTT APEC membawa dampak bagi Bali dengan didukung banyak pembangunan convention hall dan pembenahan infrastruktur.

"Tidak hanya convention hall tetapi infrastuktur dan fasilitas seperti jaringan untuk mengadakan event besar Bali bisa dikatakan sudah siap, tinggal bagaimana caranya dari sekarang mempromosikan MICE pasca APEC 2013," ungkapnya.

Mantan Bupati Gianyar yang akrab dipanggil Cok Ace ini juga mengatakan pertumbuhan convention hall hampir sekitar lima kali lipat jika dibandingkan dengan dua atau tiga tahun lalu yang hanya mencapai 2.000 saja. Saat ini, lanjutnya hampir 10.000 kapasitas guna mendukung MICE di Bali. "Memang semuanya masih terfokus di Bali Selatan yakni Nusa Dua," paparnya. "Hal tersebut yang seharusnya dipikirkan oleh industri pariwisata bagaimana Bali harus mempunyai destinasi konvensi guna mendukung pengembangan wisata MICE agar setelah KTT APEC sejumlah convenction hall di pulau ini tidak kosong," jelasnya.

Dikatakanya, dengan adanya destinasi konvensi, lanjutnya convention hall yang sudah ada tidak terabaikan begitu saja. Untuk itu bagaimana caranya kawasan Nusa Dua bisa menjadi suatu karakteristik tersendiri yaitu dengan mendongkrak wisata MICE. (ami)

Sumber: Surat Kabar Mingguan Bali Promosi, Edisi 24 Mei - 30 Mei Tahun 2013, hlm 7

\section{Teks 3: Bali Segera Bentuk Bali Convention Bureau}

\section{Bali Segera Bentuk Bali Convention Bureau}

\section{Bali Promosi}

Stakeholder pariwisata Bali merencanakan untuk segera membentuk Bali Convention Bureau guna mendatangkan dan mempertahankan event berskala internasional pasca Konferensi Tingkat Tinggi APEC 2013.

Djinaldi Gosana, Direktur Eksekutif Bali Hotels Association (BHA) mengatakan, para pemangku kepentingan industri pariwisata Bali saat ini tengah menggodok rencana untuk membentuk Bali Convention Bureau guna mempertahankan event skala internasional pasca APEC 2013.

"Saat ini Bali, memiliki kurang lebih 10.000 yang sebagian besar adalah anggota BHA untuk bisa mengadakan event besar seperti APEC, untuk itu harus ada badan atau asosiasi yang bisa mendatangkan convention yakni kegiatan yang mendatangkan pengusaha atau professional dalam jumlah besar," ujar Djinaldi.

Menurutnya, KTT APEC 2013 merupakan kesempatan besar bagi para stakeholder pariwisata untuk bersama-sama berjuang guna menghimpun semua pengusaha atau profesional agar bisa mengadakan agenda event internasional di Bali. "Seluruh stakeholder harus ada kesiapan untuk maju melakukan bidding atau penawaran untuk menjadi tuan rumah penyelenggaraan konvensi karena 
semua even bisa saja terjadi di Bali. Hanya saja, memang dibutuhkan profesional yang canggih dan kuat untuk melakukan bidding," ucapnya.

Ia juga melanjutkan, untuk membentuk sebuah badan diperlukan pendanaan maka pihaknya berharap adanya Badan Promosi Pariwisata Daerah (BPPD) Bali yang memiliki payung hukum nantinya Bali Convention Bereau akan berada di bawah BPPD Bali. "Konvensi ini tidak hanya menguntungkan pihak hotel saja atau tetapi seluruh stakeholder yang tergabung dalam Gabungan Industri Pariwisata Indonesia (GIPI) Bali,” paparnya.

Untuk itu, dia berharap Pemilihan Gubernur berlangsung aman sehingga agenda-agenda besar tahun ini tetap bisa berlangsung dan bisa berjalan untuk jangka panjang. (ami)

Sumber: Surat Kabar Mingguan Bali Promosi, Edisi 24 Mei - 30 Mei Tahun 2013, hlm 7

\section{PEMBAHASAN}

\section{KONSTRUKSI LEKSIKON “APEC”}

Wacana APEC ini digunakan dalam rangka mengambil peran menghadapi perekonomian menuju pasar bebas. Perkembangan pasar bebas telah meletakkan fondasi ikatan-ikatan ekonomi dunia melalui AFTA, APEC dan lain sebagainya. Wacana APEC telah mendorong pelaku-pelaku ekonomi dari berbagai negara untuk secara bersama melaksanakan kerjasama dalam rangka kesejahteraan warga negaranya. APEC merupakan suatu forum kerjasama dalam rangka memfasilitasi pertumbuhan ekonomi, perdagangan, dan investasi di kawasan Asia Pasifik. APEC berdiri tahun 1989 dan beranggotakan 21 ekonomi Australia, Brunei Darussalam, Canada, Chile, China, Indonesia, Jepang, Korea, Malaysia, Mexico, New Zealand, Papua New Guinea, Peru, Philipina, Russia, Singapore, China Taipei, Thailand, dan Amerika serikat. APEC menjadi forum le- gitimasi kerjasama yang penting dan strategis dalam perekonomian dunia mengingat dengan keragaman sistem politik, tingkat pembangunan/kemakmuran dan nilai sosial -budaya, maka APEC perlu mengembangkan suatu proses yang cocok untuk mencapai tujuannya bagi peningkatan kesejahteraan dan stabilitas dunia di masa mendatang.

\section{LEGITIMASI LEKSIKON}

Sebagai representasi leksikon dalam wacana APEC 2013, dapat diketahui bahwa ada terdapat sepuluh leksikon yang menjadi simbol perekonomian Bali dalam ketiga corpus data teks di atas terdiri dari: (1) kunjungan wisatawan, (2) pertumbuhan ekonomi, (3) tuan rumah, (4) perhotelan, (5) produk lokal, (6) destinasi konvensi, (7) proses penawaran (bidding process), dan (8) agenda besar. Kesepuluh konstruksi representasi leksikon dalam wacana APEC 2013 yang memberikan legitimasi dampak 
pada perekonomian Bali, akan diuraikan sebagai berikut.

Pertama, kunjungan wisatawan. Dalam perspektif pariwisata, menurut Narya (2011:48), berkembangnya pariwisata Bali tidak terlepas dari lima pilar pembangunan pariwisata, yakni masyarakat, (2) industri, (3) pemerintah, (4) akademisi, dan (5) pers. Pariwisata yang berkualitas dan pariwisata internasional memiliki ciri-ciri sebagai berikut (1) sarana dan prasarana, (2) produksi yang kreatif, (3) pelayanan yang memenuhi kepuasan wisatwan, dan (4) wisatawan yang peduli lingkungan dan budaya. Legitimasi leksikon kunjungan wisatawan termasuk dalam kategori kelompok verba. Dalam konteks APEC 2013, merupakan arus masuk kunjungan wisatawan dari berbagai negara anggota APEC diluar kunjungan wisatawan regular yang selama ini berlangsung. Kunjungan wisatawan dalam konteks APEC diprediksi akan mendorong terciptanya pertumbuhan perekonomian Bali, karena kegiatan APEC 2013 merupakan salah satu forum kerjsama multilateral yang tidak mengikat anggotanya secara legal (non legally binding). Selain itu, kunjungan wisatawan dalam kerangka APEC 2013 mencerminkan berkembangnya destinasi konvensi, convention hall, dan wisata MICE (Meeting, Incentive, Converence, Exhibition).
Kedua, pertumbuhan ekonomi. Dalam perspektif ekonomi, Narya (2011:50) mengemukakan bahwa sektor pariwisata selama ini menjadi andalan perekonomian Bali, namun belum menjadi primadona (andalan) mengingat sektor ini sangat rentan terhadap kondisi yang terjadi di sekitarnya. Pertumbuhan ekonomi berdampak pada program pengembangan pariwisata di Bali, yakni harus mampu mendorong masyarakat untuk menciptakan produkproduk lokal yang merefleksikan nilai-nilai kearifan lokal yang dimiliki masyarakat Bali (ecoturism, marine tourism, dan spiritual tourism). Legitimasi pertumbuhan ekonomi dalam teks wacana APEC 2013, dimaknai sebagai bagian dari kegiatan ekonomi kapitalisme yang bertujuan memenuhi kebutuhan pasar. Legitimasi ini diharapkan menurut Prawironegoro (2012:121;131), mampu mengubah keadaan alam menjadi kondisi yang diharapkan dalam memenuhi kebutuhan hidup yang disebut produksi kerja, serta mengubah keadaan masyarakat Bali dari tidak ada menjadi ada; atau menjadi masyarakat modern dan maju yang disebut kehidupan sosial.

Ketiga, tuan rumah. Dalam perspektif ekonomi kreatif, legitimasi dan penunjukkan sebuah negara atau wilayah menjadi tempat penyelenggaraan kegiatankegiatan bersakala nasional, regional, dan 
internasional sudah merupakan prosedur yang telah melewati keputusan bersama. Penunjukan Bali - Indonesia sebagai tempat penyelenggaraan kegiatan-kegiatan bersakala regional dan internasional seperti APEC 2013 didasarkan pada beberapa fitur semantik yang mencirikan makna tuan rumah tersebut. Fitur-fitur itu sejalan dengan jasa pelayanan yang disajikan oleh tuan rumah penyelenggara kegiatan, yakni (a) kemampuan. Sebagai tuan rumah, pengetahuan dan keterampilan tertentu wajib dan mutlak diperlukan untuk menunjang program layanan prima, yang meliputi kemampuan dalam bidang kerja yang ditekuni, melaksanakan komunikasi yang efektif, mengembangkan motivasi dan menggunakan public relation sebagai instrument dalam membina hubungan ke dalam dan ke luar organisasi/perusahaan, (b) sikap. Perilaku atau perangai sebagai tuan rumah yang baik harus ditonjolkan ketika menghadapi pelanggan, (c) penampilan. Penampilan sebagai tuan rumah sangat dibutuhkan baik secara fisik maupun non fisik, yang mampu merefleksikan kepercayaan diri dan kredibilitas dari pihak lain, (d) perhatian. Fokus perhatian dan pedulian penuh sebagai tuan rumah bagi semua tamu yang datang dengan perhatian akan kebutuhan dan keinginan tamu, (e) tindakan. Setiap tindakan yang dilakukan dalam memberikan layanan kepada kepada tamu, mencerminkan jati diri bangsa, dan (f) tanggung jawab. Keyakinan akan sebuat tanggung jawab merupakan ciri keberpihakan kepada tamu dan wujud kepedulian untuk meminimalisir resiko yang timbul.

Keempat, perhotelan. Leksikon perhotelan merupakan bentuk legitimasi ketersediaan sebuah jenis akomodasi yang mempergunakan sebagian atau seluruh bangunan untuk menyediakan jasa penginapan, makanan, dan minumam serta jasa lainnya bagi umum yang dikelola secara komersial. Penyediaan jenis penginapan menjadi bentuk legitimasi kapitalisme global bahwa event APEC 2013 akan memerlukan akomodasi yang cukup banyak dan bervariasi. Untuk itu, legitimasi leksikon perhotelan dimaknai pada beberapa fitur semantik sebagai berikut (a) transient hotel, yaitu hotel yang letak dan lokasinya di tengah kota dengan jenis tamu yang menginap sebagian besar adalah untuk urusan bisnis dan turis, (b) residential hotel, yaitu hotel yang pada dasarnya merupakan rumah - rumah berbentuk apartemen dengan kamar - kamar yang disewakan secara bulanan atau tahunan, juga menyediakan kemudahan kemudahan seperti layaknya hotel seperti restoran, pelayanan makanan yang diantar ke kamar, dan pelayanan kebersihan kamar, (c) resort hotel, yaitu hotel pada umumnya 
yang berlokasi di tempat - tempat wisata untuk melayani konsumen yang sedang berekreasi, (d) motel/motor hotel, yaitu hotel yang mempunyai lokasi sepanjang jalan raya yang menghubungkan satu kota besar dengan kota besar lainnya. Hotel jenis ini menyediakan parkir khusus seatap dengan kamar hotel.

Kelima, produk lokal. Dalam prespektif kritis pariwisata, produk lokal merupakan produk pariwisata yang berbentuk hasil unggulan dari sebuah wilayah atau area tertentu yang berdampak pada masyarakatnya. Menurut Pujani (2011:104) dan (Geriya, 2008), mengungkapkan bahwa keunggulan produk lokal memiliki ciriciri sebagai berikut (1) kreasi karyanya atau hasil kerajinan budayanya bermutu dan menjadi kebanggaan, (2) memiliki gaya yang mencerminkan identitas tertentu, (3) merepresentasikan nilai-nilai religious, dan sains yang mensinergiskan local genius, (4) dapat dan berpeluang diterima secara lokal, daerah, nasional, dan diapresiasikan sebagai puncak-puncak kebudayaan dan peradaban, dan (5) mengkritalisasikan etos, watak/spirit budaya dan humanistas yang berdimensi lokal, nasional dan global.

Keenam, destinasi konvensi. Leksikon destinasi konvensi yang terungkap dalam teks 2, merupakan kelompok kata verba yang bermakna melakukan atau mendatangi sebuah forum tertentu yang memiliki gaung secara nasional maupun internasional. Destinasi konvensi dimaknai sebagai bagian dari legitimasi wacana kapitalisme global dalam kawasan geografis yang berada pada satu wlayah administratif yang didalamnya terdapat daya tarik wisata, fasilitas umum, fasilitas pariwisata, aksesibilitas, serta masyarakat yang saling terkait dan melengkapi dalam terwujudnya cita-cita bersama. Palaguna (2011:159) mengungkapkan bahwa destinasi akan menjadi kompleks karena danya kenyataan bahwa suatu destinasi yang terkenal minimal melibatkan lebih dari satu pemerintahan daerah, baik kabupaten maupun provinsi dan berbagai satuan pemerintahan lainnya. Dalam konteks pariwisata, destinasi konvensi di Bali wajib menjadi legitimasi primadona, mengingat corak kepariwisataan Bali saat ini adalah mengandung parawisata budaya dan spiritual.

Ketujuh, proses penawaran (bidding process). Dalam perspektif hubungan internasional, Bandoro (2011:6) menyebutkan bahwa Indonesia ingin menjadi bagian penting dalam penyelesaian masalah-masalah internasional. Indonesia ingin menunjukkan keinginannya untuk memperbesar peran internasionalnya baik di tingkat global maupun regional. Slogan "Seribu sahabat tanpa musuh"akan menjadi 
produk legitimasi politik luar negeri Indonesia ke depan. Penawaran (bidding) sebagai verba proses dimaknai sebagai sebuah keinginan Indonesia untuk menjadikan bagian dari kolaborasi internasional, untuk menyelesaikan masalah-masalah internasional. Nilai penawaran ini melegitimasi pulau Bali sebagai tempat dimana terjadinya pertemuan-pertemuan tingkat internasional tersebut. Misalnya, Bali Democracy Forum (BDF) merupakan bukti nyata legitimasi internasional atas bangsa Indonesia dalam menjalankan amanat-amanat negara-negara multilateral. Leksikon proses penawaran memiliki fitur semantik yang terdiri atas: (1) menjadi acuan utama hubungan antarnegara yang mampu memberikan efek positif bagi kondisi lalu lintas internasional, (2) sebagai manifestasi dari apresiasi negara-negara maju terhadap peran internasional Indonesia (Bali) dan kemajuan pembangunan ekonomi, (3) sebagai bukti komitmen Indonesia untuk mendukung pengembangan demokrasi di negara-negara lain, dan (4) sebagai bagaian dari kerjasama regional, perluasan,dan penguatan hubungan internasional Indonesia.

Kedelapan, agenda besar. Leksikon agenda besar yang terungkap dalam teks 3, merupakan kelompok kata metafora yang bersinonim dengan kata event besar, kesempatan besar, dan even berskala internasional yang akan dilaksanakan di pulau
Bali. Dalam prespektif kerjasama multilateral, legitimasi leksikon agenda besar yang dimaksud adalah (1) agenda besar level kebijakan (policy level) yang mencakup: (a) pertemuan pemimpin ekonomi atau kepala negara/pemerintahan dalam menyusun deklarasi yang akan dijadikan agenda kebijakan bagi APEC (APEC Economic Leaders' Meeting), (b) pertemuan Menteri Luar Negeri dan Menteri Ekonomi/ Perdagangan dalam membahas kegiatankegiatan yang dilakukan dalam tahun yang bersangkutan dan menyusun rekomendasi bagi para pemimpin untuk dipertimbangkan lebih lanjut (APEC Ministerial Meeting), (c) pertemuan para menteri sektoral pada bidang: pendidikan, energi, lingkungan dan pembangunan berkelanjutan, keuangan, sumber daya manusia, kerjasama ilmu IPTEK, usaha kecil dan menegah, telekomunikasi dan informasi, pariwisata,perdagangan,perhubungan, dan peranan wanita (Sectoral Ministerial Meeting), (d) pertemuan tahunan dalam memberikan pandangan dari sisi bisnis kepada para pemimpin berkaitan dengan isu-isu APEC, menyampaikan laporan dan rekomendasi untuk meningkatkan lingkungan bisnis dan investasi dikawasan APEC (APEC Business Advisory Council-ABAC) dan (2) agenda besar level pelaksanaan (working level). 


\section{SIGNIFIKASI}

Signifikasi merupakan prosedur valid yang dicanangkan oleh Giddens (2010:49) sebagai salah satu model dari tiga dimensi struktur wacana dalam sistem sosial, dan model dalam menganalisis struktur wacana. Untuk itu, signifikasi dimensi wacana yang akan menjadi bagian dari analisis produksi wacana APEC 2013 di bidang pariwisata dan berkorelasi pada sektor perekonomian Bali. Signifikasi dalam wacana APEC 2013 mengacu pada sistem yang mengharuskan adanya relasi yang tidak dapat dipisahkan antara sebuah tanda dan realitas yang menjadi rujukannya serta bersifat ikonis. Signifikasi wacana APEC 2013 dapat diuraikan sebagai berikut.

Pertama, Kamar Dagang Industri (KADIN) sebagai tanda teks yang bersignifikasi dengan realitas sektor pariwisata dan perekonomian masyarakat Bali, yakni (1) dapat diprediksi bahwa dampak dari APEC 2013 akan mendorong jumlah kunjungan wisatawan hingga 4,5-5 juta orang, (2) memberikan peluang bagi usaha seperti sewa kendaraan, guide, travel, dan jasa penunjang wisata lainnya, (3) kabupaten Badung sebagai tuan rumah dapat mendorong terciptanya pertumbuhan ekonomi yang sukup tinggi, dan (4) semua bentuk investasi di sektor perhotelan yang digarap akan beroperasi menjelang penyelenggaraan APEC 2013 dengan jumlah hotel berbintang lima di kabupaten Badung mencapai 68 unit.

Kedua, Regulasi sebagai tanda teks yang bersignifikasi dengan realitas sektor pariwisata dan perekonomian masyarakat Bali, yakni: (1) belum adanya regulasi yang jelas terkait dengan produk makanan dan minuman yang dimanfaatkan kalangan hotel, (2) selama ini 80 persen produk makanan dan minuman dipasok dari luar Bali, (3) porsi penyerapan produk lokal ke hotel-hotel di Bali belum menunjukkan keberpihakan pada perekonomian lokal Bali, (4) realita menunjukkan bahwa pemasokan dan penggunaan produk lokal Bali masih sebatas himbauan saja, dan (5) perlu didorong dan dilakukan segera agar dikeluarkannya regulasi yang jelas dalam melindungi produk lokal Bali

\section{SIMPULAN}

Berdasarkan uraian-uraian di atas, maka wacana APEC 2013: Legitimasi dan Signifikasi Perekonomian Bali dapat disimpulkan sebagai berikut: (1) APEC 2013 merupakan suatu forum kerjasama dalam rangka menciptakan lingkungan yang aman dan efesien bagi pergerakan barang, jasa, dan manusia lintas batas negara di kawasan Asia Pasifik melalui pengaturan kebijakan dan kerjasama ekonomi dan teknik, (2) leksikon yang menjadi bukti legitimasi 
APEC 2013 melalui peran media massa terdiri atas: (a) kunjungan wisatawan, (b) pertumbuhan ekonomi, (c) tuan rumah, (d) perhotelan, (e) produk lokal, (f) destinasi konvensi, (g) proses penawaran (bidding process), dan (h) agenda besar, (3) signifikasi wacana APEC 3012 dalam sistem sosial kemasyarakatan yang berdampak pada perekonomian Bali terdiri atas: (a) Kamar Dagang Industri (KADIN), (b) regulasi, (c) Badan Promosi Pariwisata Daerah (BPPD), dan (d) Bali Hotels Accosiation (BHA).

Selain itu, secara umum APEC 2013 yang diwacanakan berlangsung di Bali, akan berdampak besar pada pembangunan sektor pariwisata. Setidaknya, signifikasi perubahan dan dinamika yang terjadi di tingkat nasional, regional dan internasional akan dikonstruksi dan didayagunakan secara bersama dalam menyelesaikan berbagai persoalan yang sama pada sesama negara anggota APEC. Signifikasi APEC 2013 pada sektor pariwisata di Bali diharapkan menjembatani dan menuntaskan fenomena klasik yang sering dihadapi, yakni dampak ekonomi global yang berkepanjangan mengakibatkan menurunnya daya investasi pada sektor pariwisata dan menurunnya kinerja investasi mega proyek pembangunan pariwisata; (2) keberpihakan pada warisan budaya lokal belum secara optimal menjanjikan; (3) sinergitas dan penguatan kapasitas antarstakeholder yang berkepentingan belum signifikan; dan (4) otonomi daerah yang dibenturkan pada peraturan kepariwisataan nasional.

Rekomendasi

Berdasarkan uraian-uraian di atas, maka saran yang dapat dijadikan sebagai kontribusi dalam rangka peningkatan pembangunan sektor pariwisata pada masyarakat Bali adalah: (a) penyelenggaraan eventevent berskala nasional dan internasional diharapkan dapat menyebar atau merata di semua wilayah tujuan wisata di Bali, (b) keikutsertaan para pelaku/stakeholder, kelompok sukarelawan, asosiasi wisata, asosiasi bisnis dan pihak-pihak lain yang berpengaruh dan berkepentingan melalui event APEC 2013 dan sejenisnya yang dapat berdampak positif pada pariwisata Bali, (c) Pemerintah Pusat dan Pemerintah Daerah Provinsi Bali harus memberi jaminan rasa aman dan nyaman bagi setiap pengunjung yang datang pada event APEC tersebut, serta meminimalisir pelaku pariwisata atau sejenisnya dari konflik politik yang mengarah pada NKRI, dan (d) Pemerintah Pusat dan Pemerintah Daerah Provinsi Bali harus terus menerus melakukan upaya promosi yang memperkuat karakter bangsa dan identitas masyarakat setempat yang bertujuan untuk mewujudkan perdamaian yang dicita-citakan, pengalaman berwisata 
yang berkualitas, dan memberikan kepuasan bagi peserta APEC 2013 tersebut.

\section{UCAPAN TERIMA KASIH}

Penulis mengucapkan terima kasih kepada Mitra Bestari yang memberikan masukanmasukan yang sangat bermanfaat untuk perbaikan artikel ini. Atas masukanmasukan yang telah diberikan sekali lagi penulis mengucapkan terima kasih

\section{DAFTAR PUSTAKA}

Bandoro, B. 2011. "Indonesia ingin menjadi bagian penting melalui Penyelesaian Masalah-Masalah Internasional" dalam Tabloit Diplomasi. Media Komunikasi dan Interkasi, No.40 Tahun IV. Tanggal 15 Februari-14 Maret 2001. Jakarta: Direktorat Diplomasi Publik- KEMENLU RI.

Geriya, I.W. 2008. "Pembangunan Bali Berbudaya dan Bervitalisasi Etos Keunggulan untuk Bangkit" dalam Prosiding Kongres Kebudayaan Bali I Tahun 2008. Denpasar: Panitia Kongres Kebudayaan Bali 2008.

Narya, Ketut. 2011. "Kebijakan Pemerintah Provinsi Bali mewujudkan Destinasi Bali yang Sustainable" dalam Pariwisata Berkelanjutan pada Pusaran Krisis Global (Putu Anom, dkk). Denpasar: Universitas Udayana Press.

Pilliang, Yasraf Amir. 2005. Transpolitika. Dinamika Politik di dalam Era Virtualitas. Yogyakarta: Jalasutra. . 2010. Post-Realitas. Realitas Kebudayaan dalam Era PostMetafisika. Yogyakarta: Jalasutra.

Petraton, Ade. 2012. "Kemelut dan Hasil Konferensi Tingkat Tinggi Menteri ke-13 di Doha" dalam Diplomasi Multilateral, Buletin Kementerian Luar Negeri Republik Indonesia. Jakarta: SETJEN KEMENLU RI.

Pujani, L.P.K. 2011. "Pemberdayaan Komunitas Pedagang Souvenir Asal Kintamani di Kota Denpasar" dalam Pariwisata
Berkelanjutan pada Pusaran Krisis Global (Putu Anom, dkk). Denpasar: Universitas Udayana Press.

Prawirinegoro, Darsono. 2013. Karl Marx: Ekonomi Politik dan Aksi Revolusi. Jakarta: Nusantara Consulting.

van Leeuwen, T., \& Wodak, R. 1999. Legitimizing Immigration Control: A DiscourseHistorical Perspective. Discourse Studies, 1: 83-118.

van Leeuwen, T. 2008. Discourse and Practice. New Tools for Critical Discourses Analysis. Oxford-New York: Oxford University Press. 